\title{
Unintended Consequences
}

Reconsidering the Effects of UN Peacekeeping on State-sponsored Violence

\author{
William G. Nomikos ${ }^{1}$
}

Danielle N. Villa ${ }^{2}$

\begin{abstract}
This essay challenges theoretical and empirical arguments about peacebuilding effectiveness that put the state at the center of United Nations peace operations. We suggest that state-centric UN peacebuilding operations might inadvertently incentivize local-level violence in post-conflict settings. When the UN supports central governments it may unintentionally empower nonprofessionalized militaries, paramilitaries, and warlords to settle local scores. Armed violence against civilians in turn triggers a vicious cycle of reprisals and counter-reprisals. As an alternative to state-centric peacebuilding operations that carry the risk of enflaming local tensions, we suggest that the UN would benefit from shifting strategic resources away from central governments and toward UN policing, support of traditional and religious authorities, and the training of local security institutions.
\end{abstract}

${ }^{1}$ Corresponding Author. Assistant Professor, Department of Political Science, Washington University in St. Louis. Email: wnomikos@wustl.edu.

${ }^{2} \mathrm{PhD}$ candidate, Department of Political Science, Emory University and Predoctoral Fellow, Institute for Security and Conflict Studies, the George Washington University. 


\section{Introduction}

The ongoing civil war in Mali (2012-2021) began as a separatist conflict in the northern part of the country. MINUSMA, the UN peacekeeping operation in the country, deployed explicitly in response to this conflict. Yet, in recent years violence has spread to central Mali, drawing in members of the Peulh ethnic group. What accounts for the spread of violence in Mali and the salience of a new ethnic cleavage despite the support of robust peacebuilding operations? Likewise, why does violence persist, evolve, or emerge in other contexts featuring UN peacekeepers?

We suggest that United Nations peacebuilding operations may inadvertently incentivize local-level violence. UN peacebuilding operations materially support domestic governments' efforts to maintain order following conflict. However, domestic governments and their armed forces often use their power to settle local scores rather than keep the peace. The governmental abuse of power may thus instigate a new local-level cycle of violence divorced from the original conflict.

This essay makes three contributions relevant to debates about peacekeeping in academia and the policy-world. First, it highlights the wide range of actors that peacekeepers interact with, encouraging scholars to understand a broader range of peacekeeper-armed actor dynamics. Second, we explain how UN support of formal state institutions can unintentionally contribute to local-level conflicts in peacebuilding operations. Third, the essay highlights alternative peacebuilding strategies for analysts and practitioners of peacebuilding operations alike. Ultimately, our essay complements the contributions by Tucker \& Kathman as well as Roy \& Newton in this issue to further unpack the nature of the "peace" that UN peacekeepers maintain in post-conflict settings. 


\section{How the UN Promotes Peace}

How does peacebuilding work? Existing cross-national research on peacekeeping is largely optimistic about operations' likelihood of success. Scholars have emphasized how international peacebuilders can help belligerents overcome commitment problems (Walter 2002; Fortna 2008). As Tucker \& Kathman discuss in their essay in this issue, UN peacekeeping is an especially effective tool for crafting negative peace, understood as the absence of violence. ${ }^{3}$ Subsequent expansions have applied these theories to local-level outcomes ${ }^{4}$ as well as to civilian protection, both in wartime and after conflict. ${ }^{5}$ These studies have shown that UN peacekeepers prevent violence from breaking out both nationally as well as sub-nationally.

Yet moving from a negative peace to a positive peace, understood as addressing the structural conditions for conflict, has proven more elusive, as Roy \& Newton show in their contribution to this issue. ${ }^{6}$ Much of the existing work assumes that statebuilding is the most effective means to promote the rule of law. Statebuilding refers to international efforts to support a post-conflict state's capacity to resolve future conflicts peacefully. Statebuilding can bolster institutional legitimacy, improving long-term prospects for peace. ${ }^{7}$ International actors can lend legitimacy to post-conflict states, as well as support public goods provision. ${ }^{8}$

\footnotetext{
3 Tucker and Kathman, "UN Peacekeeping Effectiveness and Negative Peace."

${ }^{4}$ Ruggeri, Dorussen, and Gizelis, "Winning the Peace Locally."

${ }^{5}$ Hultman, Kathman, and Shannon, "United Nations Peacekeeping and Civilian Protection in Civil War"; Hultman, Kathman, and Shannon, "Beyond Keeping Peace."

${ }^{6}$ Roy and Newton, "From Negative to Positive Peace: Contributions of UN Peacekeeping."

${ }^{7}$ Blair, "Legitimacy After Violence."

${ }^{8}$ Lake, "The Practice and Theory of US Statebuilding."
} 
However, existing research suggests international actors lack the capacity, ${ }^{9}$ legitimacy, ${ }^{10}$ or local know-how ${ }^{11}$ to help consolidate gains from peace into successful statebuilding at the end of which local populations view the state as legitimate. Others have pointed out that UN peacebuilding features a liberal concept of state-society relations. Scholars criticize universal peacebuilding models as fundamentally unsuited to many post-conflict contexts ${ }^{12}$ or failing to account for local-level failures. ${ }^{13}$ Thus, a key tension is the discrepancy between the optimistic cross-national evaluations of peacebuilding and recent critical approaches; we directly address this tension. We show that UN peacebuilders effectively stop existing conflicts but may also increase the prospects of new types of conflict breaking out.

\section{Moving Away from the State}

We suggest that UN peacebuilding efforts can create incentives for new conflict in a postconflict state. In particular, we identify a pathway by which statebuilding can create new conflict in unintended ways. UN operations are fundamentally state-centric. Many peacebuilding operations are tasked with extending the authority of the state ${ }^{14}$ and provide benefits to increase state capacity. ${ }^{15}$ Likewise, peacekeepers in civil wars deploy where their military benefits can best support host governments. ${ }^{16}$ Strong states can better maintain the monopoly on the use of violence and thus reduce violence against civilians. ${ }^{17}$

\footnotetext{
${ }^{9}$ Beardsley, "Agreement without Peace?"

${ }^{10}$ Lake, The Statebuilder's Dilemma.

${ }^{11}$ Autesserre, The Trouble with the Congo; Autesserre, Peaceland.

${ }^{12}$ Lynch, "Neoliberal Ethics, the Humanitarian International, and Practices of Peacebuilding."

${ }^{13}$ Autesserre, Peaceland.

${ }^{14}$ Missions such as those in Sierra Leone (UNAMSIL) and the DRC (MONUSCO) have been mandated to reestablish, extend, or consolidate the authority of the state.

15 Di Salvatore and Ruggeri, "The Withdrawal of UN Peace Operations and State Capacity."

${ }^{16}$ Villa, Externalities of Consent.

17 Zimmerman, "Defining State Authority."
} 
However, UN peacebuilding operations may in this way also unintentionally incentivize local-level conflict through their support of central government and their militaries. ${ }^{18}$ The UN prioritizes the creation of order and security in post-conflict zones, often delegating this task to domestic states and their armed forces. Governments use UN-provided support, resources, and legitimization to create and maintain order. However, in most developing states, governments rely on non-professionalized militaries, warlords, and paramilitary forces to keep the peace. These groups create conflict and perpetuate grievances that lead to further local-level violence.

Violence against civilians can motivate and prompt new cycles of conflict. A new violent conflict cycle can occur through three sequential processes, as diagrammed in Figure 1. First, non-professionalized armed groups commit violent acts against civilians. Although the UN empowers these armed groups to keep the peace and prevent rebel groups from attacking civilians, they often use their newfound power to settle local scores. For example, members of the Malian military (Forces Armées Maliennes or FAMA), predominantly members of Mali's dominant ethnic groups, have frequently victimized civilians from ethnic group competitors since the deployment of the UN.

${ }^{18}$ Duursma, "Pinioning the Peacekeepers." 


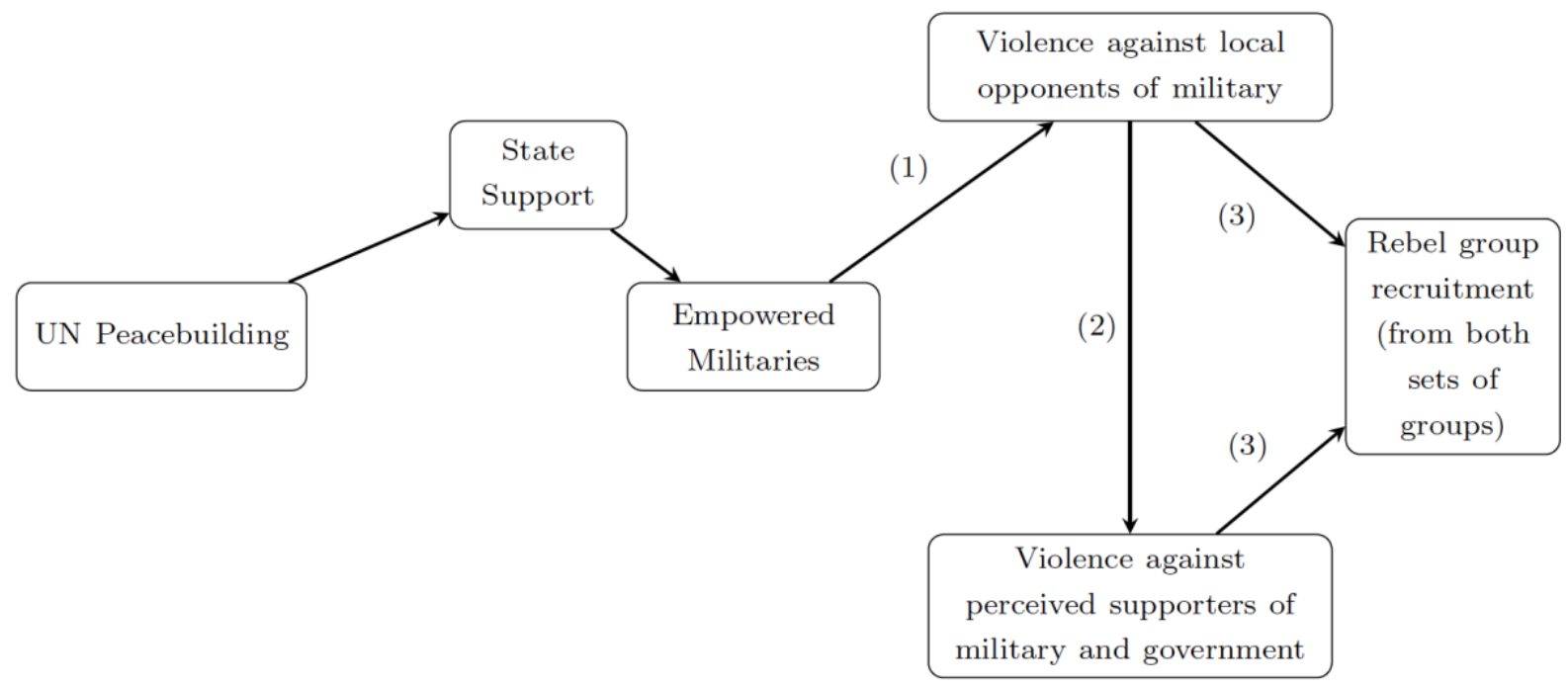

Figure 1: Diagram of argument, how UN peacekeeping inadvertently creates new salient conflicts

Second, local populations retaliate against supporters of the armed groups and vice versa. Retaliation cycles are common and easily triggered following civil war violence. ${ }^{19}$ Victims of armed group violence do not feel like they can rely on the government or the UN, since these actors supported the perpetrators. As a result, they resort to attacking perceived supporters of the armed group, the government, or the UN. The victims of this violence retaliate, perpetuating an all-new cycle of local-level conflict. Returning to the example of the Malian military, victims of military violence have retaliated against civilians that they believe support the government.

Third, new armed groups emerge to meet the demand for new violence, recruiting from ethnic groups attacked by state-supported militaries or from ethnic groups facing retaliatory attacks. As a result, UN support of a central government can inadvertently create new fronts of violence that can threaten the entire state's stability. The groups carrying out this violence are

\footnotetext{
${ }^{19}$ Bateson, Order and Violence in Postwar Guatemala.
} 
ubiquitous in conflict, are highly violent, and contribute to overall disorder. ${ }^{20}$ Figure 2 demonstrates the rise of militias engaging in violence against civilians in the African countries hosting peacekeepers between 1997-2018. ${ }^{21}$

Our contention is not that this cycle of violence always occurs, that UN peacekeeping operations inevitably incentivize new conflicts, or that when it does occur the vicious cycle outweighs the positive elements of UN peacekeeping entirely. Along the lines of Roy \& Newton's essay in this issue, we merely wish to identify a possible and important challenge to positive peacebuilding.

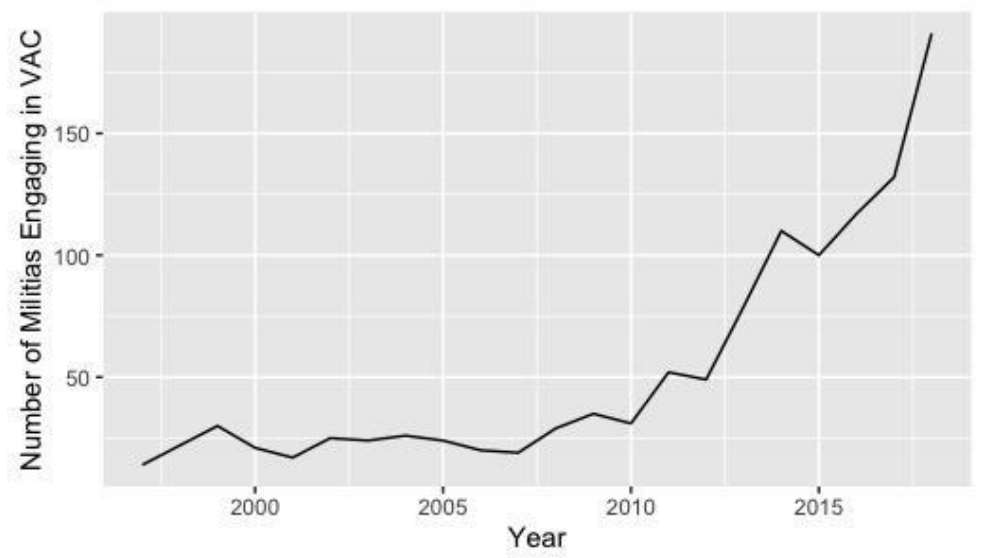

Figure 2: The Number of Militias Engaging in Violence Against Civilians in African Countries Hosting a Peacekeeping Operation, 1997-2018

\section{Alternative Approach}

We do not argue that the United Nations should entirely abandon programs that support the state or that attempt to build the state-security apparatus. Rather, policymakers should

\footnotetext{
${ }^{20}$ Carey and Mitchell, "Progovernment Militias."

${ }^{21}$ Burundi, CAR, Chad, Cote D'Ivoire, DRC, Ethiopia, Eritrea, Liberia, Mali, Morocco, Sierra Leone, Sudan, and South Sudan. These data come from Raleigh et al. 2010.
} 
consider shifting peacekeeping resources away from post-conflict governments. In particular, three non-state centric peacebuilding strategies hold great promise moving forward: (1) locallevel peace enforcement by United Nations police forces and peacekeepers; (2) training of local police forces and security brigades independently of the state; (3) cooperation with traditional and religious authorities.

First, instead of empowering governments and their non-professionalized militaries to enforce local-level peace in post-conflict states, UN peacekeepers and UN police can directly enforce local-level peace. Peacekeepers use a strategic posture in order to stop current violence and deter future violence. From the perspective of the local population, the practical implication is that violence is no longer considered a feasible strategy for solving a local-level dispute. This is because of the high likelihood that the UN will stop or punish the violence later, which citizens assume the military would not do. Recent evaluations at the micro- and sub-national levels suggest that direct $\mathrm{UN}$ enforcement can effectively increase interethnic cooperation and reduce violence. ${ }^{22}$ Direct UN enforcement of local-level peace can alleviate the need for central governments to rely on their non-professionalized security forces. It can also provide the UN time to help governments professionalize and reform the security sector. ${ }^{23}$

Second, the UN should continue to embrace non-state centric peacebuilding operations. In particular, the UN should cooperate with non-state authorities that carry a great deal of legitimacy in developing country settings. Traditional authorities typically play a central role in resolving disputes in these contexts, particularly in small rural communities. These leaders can

\footnotetext{
${ }^{22}$ Hunnicutt and Nomikos, "Nationality, Gender, and Deployments at the Local Level"; Nomikos 2021; Nomikos 2022; Ruggeri, Dorussen, and Gizelis,"Winning the Peace Locally." See Autesserre, The Trouble with the Congo for a critique of UN operations in the Democratic Republic of Congo because they de-emphasized local-level security.

${ }^{23}$ Karim and Gorman, "Building a More Competent Security Sector."
} 
facilitate aid provision and peacebuilding in post-conflict societies. ${ }^{24}$ Similarly, recent research suggests that religious leaders can mobilize collective action in post-conflict settings, especially when embracing Qur'anic scripture. ${ }^{25}$

Finally, in conflict settings that necessitate some degree of local order-building, the UN should shift resources away from formal institutions such as militaries to local security institutions comprised of local volunteers trained by UN experts. The United States has achieved above-average peacebuilding outcomes with such programs - the Sons of Iraq and Afghan Local Police (ALP) programs in Iraq and Afghanistan. The effectiveness of these local security institutions derives from those community members who volunteer to serve in the police force and the community leadership that helps international peacebuilders recruit volunteers. This is no easy task. The peacebuilder - in this case the UN—must identify and monitor potential local leaders that can serve as agents that can help recruit volunteers. These leaders must be competent, carry a great deal of legitimacy and community-level trust, and must be interested in community-level peace. Once American peacebuilders selected training sites for the ALP program, local police would be trained by American advisors but governed by local councils (shuras) and tasked strictly with keeping local-level peace. The shuras would designate leaders that would oversee the ALP. The shuras, which are viewed as legitimate actors by the local populace, would bestow legitimacy on the security personnel. The ALP-leadership would be vetted by government officials, who would impose their own preferences on selecting leaders. Thus, American leaders had to have enough information to select suitable training sites, shuras, and government officials to vet police leaders and volunteers. While such programs do not

\footnotetext{
${ }^{24}$ Baldwin, The Paradox of Traditional Chiefs in Democratic Africa; Blattman, Hartman, and Blair, "How to Promote Order and Property Rights under Weak Rule of Law?"

${ }^{25}$ Condra, Isaqzadeh and Linardi, "Clerics and Scriptures"; Masoud, Jamal, and Nugent, "Using the Qur'an to Empower Women"; Grossman, Nomikos, and Siddiqui, "The Limits of Religious Messaging."
} 
entirely eliminate the state, they incorporate local, non-governmental stakeholders that can minimize the involvement of non-professionalized militaries.

In this essay, we have suggested that UN peacebuilding operations may unintentionally create incentives for new conflict. Our essay thus complements the essays by Tucker \& Kathman and by Roy \& Newton to highlight potential challenges in crafting a positive peace in postconflict settings. In her contribution to this issue, Lisa Hultman discusses how the UN has over the past 75 years moved away in its doctrine from a focus on state security to a focus on human security. We have outlined a key challenge that UN peacekeeping practice may still face in implement this doctrinal shift. At the same time, we also make the case that the incentivization process that may be triggered by UN peacekeeping operations is avoidable. With some shifting of resources and strategic prioritization, the UN can help prevent the unintentional creation of new local-level cycles of violence.

\section{References}

Autesserre, Severine. The Trouble with the Congo: Local Violence and the Failure of International Peacebuilding. New York, NY: Cambridge University Press, 2010.

Autesserre, Severine. Peaceland: Conflict Resolution and the Everyday Politics of International Intervention. New York, NY: Cambridge University Press, 2015.

Baldwin, Kate. The Paradox of Traditional Chiefs in Democratic Africa. New York, NY: Cambridge University Press, 2015.

Bateson, Regina A. Order and Violence in Postwar Guatemala. PhD thesis, 2013.

Beardsley, Kyle. "Agreement without Peace? International Mediation and Time Inconsistency Problems.” American Journal of Political Science 52, no. 4 (2008):723-740.

Blair, Robert. "Legitimacy After Violence: Evidence from Two Lab-in-the-Field Experiments in Liberia." Working Paper (2016). URL: https://papers.ssrn.com/sol3/papers2.cfm?abstract_id=2326671. 
Blattman, Christopher, Alexandra C. Hartman, and Robert A. Blair. "How to Promote Order and Property Rights Under Weak Rule of Law? An Experiment in Changing Dispute Resolution Behavior Through Community Education.” American Political Science Review 108, no. 1 (2014).

Condra Luke N., Mohammad Isaqzadeh, and Sera Linardi. "Clerics and Scriptures:

Experimentally Disentangling the Influence of Religious Authority in Afghanistan." British Journal of Political Science 49, no. 2 (2017): 1-19.

Carey, Sabine C. and Neil J. Mitchell. "Progovernment Militias." Annual Review of Political Science, 20 (2017): 127-127.

Di Salvatore, Jessica and Andrea Ruggeri. "The Withdrawal of UN Peace Operations and State Capacity: Descriptive Trends and Research Challenges.” International Peacekeeping 27, no. 1 (2020): 12-21.

Duursma, Allard. "Pinioning the Peacekeepers: Sovereignty, Host-State Resistance against Peacekeeping Missions, and Violence against Civilians. International Studies Review (2020).

Fortna, Virginia Page. Does Peacekeeping Work? Shaping Belligerents Choices after Civil War. Princeton, NJ: Princeton University Press, 2008.

Grossman, Allison, William G. Nomikos, and Niloufer Siddiqui. "The Limits of Religious Messaging: Promoting Social Cohesion among Adolescents in Burkina Faso?" Journal of Experimental Political Science (2022).

Hunnicutt, Patrick and William G. Nomikos. "Nationality, Gender, and Deployments at the Local Level: Introducing the RADPKO Dataset." International Peacekeeping 27, no. 4 (2020): 645-672.

Hultman, Lisa, Jacob Kathman, and Megan Shannon. "United Nations Peacekeeping and Civilian Protection in Civil War." American Journal of Political Science 57, no. 4 (2013): 875-891.

Hultman, Lisa, Jacob Kathman, and Megan Shannon. "Beyond Keeping Peace: United Nations Effectiveness in the Midst of Fighting." American Political Science Review 108, no. 4 (2014): 737-753.

Karim, Sabrina and Ryan Gorman. "Building a More Competent Security Sector: The Case of UNMIL and the Liberian National Police." International Peacekeeping 23 no.1 (2016):158-191.

Lake, David. The Statebuilder's Dilemma: On the Limits of Foreign Intervention. Ithaca, NY: Cornell University Press, 2015. 
Lake, David. "The Practice and Theory of US Statebuilding." Journal Of Intervention And Statebuilding 4, no. 3 (2010): 257: 284.

Lynch, Cecelia. "Neoliberal Ethics, the Humanitarian International, and Practices of Peacebuilding." In Globalization, Social Movements, and Peacebuilding, edited by Jackie Smith and Ernesto Verdeja, 47-68. Syracuse, NY: Syracuse University Press, 2013.

Masoud, Tarek, Amaney Jamal, and Elizabeth Nugent. Using the Qur'ān to Empower Arab Women? Theory and Experimental Evidence from Egypt. Comparative Political Studies 49, no. 12 (2016):1555-1598.

Nomikos, William G. "Peace Is in the Eye of the Beholder: How Perceptions of Impartiality Shape Peacekeeping Outcomes.” SocArXiv (2022). doi:10.31235/osf.io/q5snx.

Nomikos, William G. "Peacekeeping and the Enforcement of Intergroup Cooperation: Evidence from Mali." Journal of Politics (2022).

Raleigh, Clionadh, Andrew Linke, Havard Hegre, and Joakim Karlsen. "Introducing ACLED: An Armed Conflict Location and Event Dataset: Special Data Feature." Journal of Peace Research 47, no. 5 (2010): 651-660.

Ruggeri, Andrea, Han Dorussen, and Theodora-Ismene Gizelis. "Winning the Peace Locally: UN Peacekeeping and Local Conflict.” International Organization 71 no.1 (2017):163185.

Villa, Danielle N. Externalities of Consent: UN Peacekeeping Operations and Host Government Consent. $\mathrm{PhD}$ thesis, 2021.

Walter, Barbara F. Committing to Peace: The Successful Settlement of Civil Wars. Princeton, New Jersey: Princeton University Press, 2002.

Zimmerman, S. "Defining State Authority: UN Peace Operations Efforts to Extend State Authority in Mali and the Central African Republic." Stability: International Journal of Security and Development 9(1) 2020. 